\title{
Wanton disfiguration of famous \\ Skaergaard outcrop deplored
}

\author{
David Bridgwater, F. Bryan Davies, Robin C. O. Gill, \\ Barry E. Gorman, John S. Myers and Paul Taylor
}

A classic outcrop of the Skaergaard intrusion, first described and made famous in the original description of this area of East Greenland by Wager \& Deer (1939, pl. 11, figs 1 and 2) was visited in 1977 and found to have been senselessly vandalised. We consider this to be inexcusable. The Skaergaard intrusion is unequalled in igneous petrology as an example of crystal fractionation and magmatic evolution, and has been the subject of extensive research since its discovery (see bibliography in the 1962 reprint of Wager \& Deer, 1939; Wager \& Brown, 1968).

The outcrop occurs about $120 \mathrm{~m} \mathrm{NNE}$ of the site of the main base house of the 1935-1936 British East Greenland Expedition, and is part of trough banding structure $F$ (located in Wager \& Deer, 1939, fig. 11). It is one of the best examples of trough banding in the area, showing the clearest separation of mafic minerals and plagioclase in a section normal to the trough axis. It was figured again as such by Wager \& Brown (1968, figs 52 \& 53) and is reproduced here in fig. 4 from the original plate. At least 23 closely spaced drill holes had been sunk into the outcrop to remove a slab, part of which remains at the base of the outcrop.

Had this operation been warranted for scientific research, then a single core from above would have sufficed, and would not have been visible on the main face of the outcrop. Alternatively, numerous loose blocks in the vicinity would have proved adequate for both teaching and display purposes. If these loose blocks were considered inadequate, it would have been a simple matter with a portable drill to remove a block from one of the other less famous trough bands.

It is unlikely that those responsible were in ignorance of Wager \& Deer's (1939) description of this outcrop, and to despoil a locality made famous by others, for no valid scientific purpose is both despicable and irresponsible. The remoteness of the locality provides no excuse for this action, since it is likely that as travel becomes easier an increasing number of geologists will be privileged to visit this famous area. One might argue that only a small part of this outcrop was taken and that what remains is sufficient to show how it was in its entirety. But this is no more reasonable than the removal of part of a famous sculpture or painting; it is for the visual effect of the entity as well as details of its parts that it is viewed.

The act of premeditated selfishness which resulted in the disfiguration of one of Skaergaard's most famous localities is of the kind that collectively impoverishes the environment for ourselves as well as future generations of naturalists. No localities of geological interest are protected by law in Greenland, as is the case in some countries, and it was assumed that this would not be necessary. We hope that the kind of wanton damage described here will not recur, and that classic sites such as this will be protected by geologists themselves in respect of their legacy to future generations. 

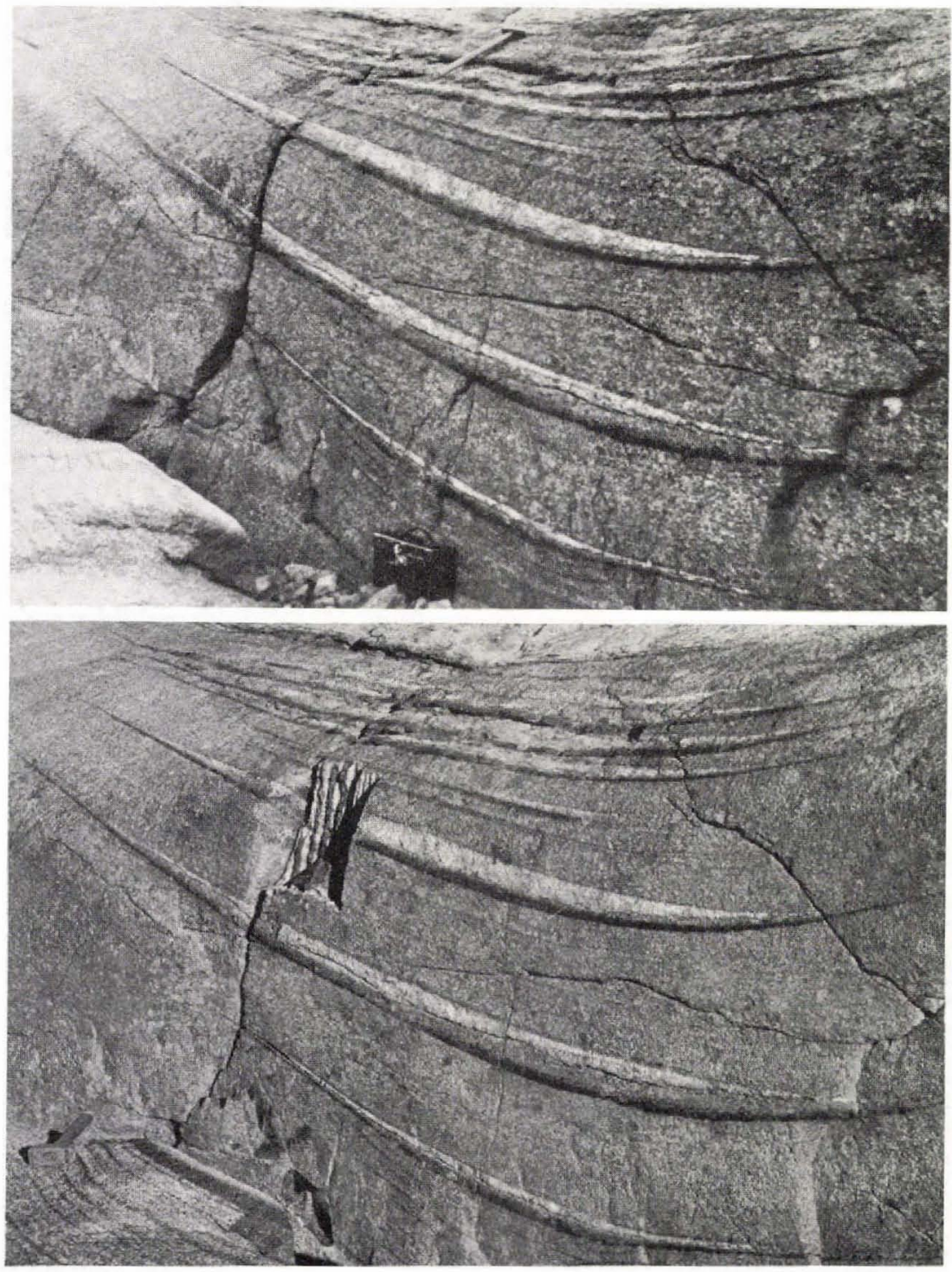

Fig. 4. Above: trough banding structure $\mathrm{F}$ in Upper Zone as seen in profile; from Wager \& Deer, 1939, Plate 11, Fig. 2. Below: same exposure as seen in August 1977, showing damage caused by the removal of a slab about $50 \times 50 \times 15 \mathrm{~cm}$. 


\title{
References
}

Wager, L. R. \& Brown, G. M. 1968: Layered igneous rocks, 588 pp. Edinburgh: Oliver \& Boyd.

Wager, L. R. \& Deer, W. A. 1939: Geological investigations in East Greenland. Part III. The petrology of the Skaergaard intrusion, Kangerdlugssuaq, East Greenland. Meddr Grønland 105,4, 352 pp.

$\begin{array}{ll}\text { F.B.D., } & \text { R.C.O.G. \& P.T., } \\ \text { 5 Silver Street } & \text { Department of Geology and Mineralogy, } \\ \text { Gastard, } & \text { University of Oxford, } \\ \text { Corsham, Wilts, } & \text { Oxford OX1 } 3 P R, \\ \text { U.K. } & \text { U.K. }\end{array}$

B.E.G., Department of Geology, University of Western Ontario, London, Ontario N5A 5B7, Canada.

\section{Geological investigations in Lower Palaeozoic terrain of northern Greenland between $78^{\circ} 30^{\prime} \mathrm{N}$ and $81^{\circ} 30^{\prime} \mathrm{N}$}

\author{
John S. Peel
}

The 1977 field season concluded a three year programme in Washington Land (Henriksen \& Peel, 1976; Peel, 1977) aimed at the compilation of standard profiles through the Lower Palaeozoic and the ultimate production of a 1:500 000 geological map. Members of the party of six worked in Washington Land, southern Hall Land and Inglefield Land (fig. 5) with the support of a Greenlandair Charter Bell 204 helicopter periodically travelling north from Thule Air Base.

The season commenced at Alakratiak Fjord where excellent sections through the Upper Ordovician and Lower Silurian provided a link between Ordovician and Silurian sections compiled in the previous season by Peel and J. M. Hurst (GGU), respectively. A prominent cliff-forming limestone unit was found to include both the highest unit of the Ordovician Cape Calhoun Formation of Koch (1929a) and equivalents of the lowest Silurian Cape Schuchert Formation of Koch (1929b).

$J$. M. Hurst and H. F. Jepsen (GGU) studied various sections in the Silurian platform carbonate sequences exposed in the northern part of Washington Land, around Bessel Fjord. Here, some $2000 \mathrm{~m}$ of limestones, limestone breccias, dolomites and thin interbedded shales, including strata which Koch (1929b) referred to the Offley Island Formation, pass south-westwards into basinal graptolitic shales, cherty black limestones and biostromal limestone, with carbonate mounds. There is an apparently continuous section from known Upper Ordovician to known lower Upper Llandovery, suggesting that the whole of the Lower and Middle Llandovery may well be present.

Hurst also visited Kap Tyson in Hall Land to investigate the Offley Island and Cape Tyson Formations of Koch (1929b). The Offley Island Formation is recognisable in Washington 